\title{
Аналітичне дослідження та обгрунтування показників роботи польового культиватора «FLORIN» для виробничих умов
}

\author{
О.В. Таценко ${ }^{1}$, А.В. Мартинюк ${ }^{2}$, В.С. Курской ${ }^{3}$ \\ ${ }^{1}$ Сумський національний аграрний університет (м. Суми, Украӥна) \\ 2,3 Хмельницький національний університет (м. Хмельницький, Україна) \\ email:1 alextatsenko@ukr.net, 2 av.mart@ukr.net, ${ }^{3}$ vk702713@gmail.com \\ ORCID: ${ }^{1}$ 0000-0003-1762-8219, ${ }^{2}$ 0000-0001-8277-1308, ${ }^{3}$ 0000-0002-3929-884X
}

\begin{abstract}
У технологіях вирощування сільськогосподарських культур найбільші резерви енергозбереження та підвищення продуктивності сільськогосподарських культур мають способи обробітку ґрунту. Сучасні тенденції сільськогосподарського виробництва потребують обґрунтування, запровадження і використання раціональних сучасних ґрунтообробних знарядь та вдосконалення існуючих технологічних процесів обробітку ґрунту.

Проаналізовано останні дослідження та публікації напрямків підвищення ефективності обробітку ґрунту під сільськогосподарські культури та використання технічних засобів для їх реалізації в умовах чорноземних ґрунтів України.

Проведено наукові дослідження показників роботи польового культиватора «FLORIN» при поверхневому обробітку грунту під зернові культури у виробничих умовах, при яких ресурси будуть використовуватися найбільш ефективно. Процес обґрунтування показників роботи польового культиватора «FLORIN» проводився за рахунок вибору більш раціонального і ефективного складу та режимів роботи машинних агрегатів для поверхневого обробітку грунту під зернові культури у виробничих умовах.

В статті наведені аналітичні результати дослідження та обгрунтування показників роботи польового культиватора «FLORIN» для виробничих умов в технологіях вирощування сільськогосподарських культур.

При дослідженнях, які проводились відповідно до розробленої методики, визначались показники показників роботи польового культиватора «FLORIN».

Ефективність використання польового культиватора «FLORIN» при передпосівному обробітку грунту під зернові культури для для виробничих умов залежить від правильного вибору показників роботи та підбору енергетичного засобу для грунтообробного агрегату.

Вибір оптимального діапазону робочих швидкостей для польового культиватора «FLORIN» при обробітку грунту під зернові культури у виробничих умовах дає можливість підвищити показники використання машинних агрегатів, а також скоротити витрати ресурсів на виконання технологічних процесів при виробництві сільськогосподарської продукції.

Правильність вибору режимів роботи грунтообробних машинних агрегатів даного виду та раціонального діапазону робочих швидкостей для польового культиватора «FLORIN» залежить від врахування виробничих умов.
\end{abstract}

Ключові слова: технологічний процес, обробіток ґрунту, передпосівний обробіток грунту, технічні засоби, культиватор «FLORIN», комплектування машинних агрегатів, режими роботи, показники роботи.

Постановка проблеми. Головна умова розвитку сільського господарства полягає в створенні економічних умов, що забезпечують розширене відтворення (тобто збільшення виробництва продукції з кожного гектара), впровадження сучасних досягнень науково-технологічного прогресу, закріплення і розвиток матеріально-технічної бази, комплексну механізацію та автоматизацію виробничих процесів.
Розробка правил раціональної експлуатації техніки і її реалізація передбачає формування системи машиновикористання. Така необхідність обумовлена в умовах збільшення потреби в новій техніці. Впровадження сучасних засобів механізації сільськогосподарського виробництва і постійне підвищення ефективності використання сільськогосподарської техніки, головні напрямки інтенсифрікації сільського господарства. Важливими 
особливостями сільськогосподарського виробництва по відношенню до інших галузей являється:

- виконання польових робіт (технологічних операцій) повинно здійснюватися в оптимальні періоди року і часто в стиснуті терміни;

- сільськогосподарське виробництво розташоване в різноманітних ґрунтово-кліматичних зонах.

Сільськогосподарське виробництво держави базується на широкому використанні сучасної високопродуктивної техніки, яка по мірі свого розвитку становиться все більш складнішою. В систему машин увійшло близько 110 комбінованих та ґрунтообробних машин 3 активними робочими органами. Створюється нове поповнення сільськогосподарської техніки - більш потужної, яка забезпечує високу якість виконання робіт та поточну організацію процесів виробництва. Удосконалення сільськогосподарської техніки в першу чергу означає значне підвищення ії̈ надійності, відповідність машин енергонасиченим тракторам, комплектність поставки тракторів з машинами і знаряддями. Щоб в цих умовах забезпечити постійну роботоздатність машинно-тракторного парку, в господарстві повинно бути організовано кваліфіковане використання техніки і її раціональний підбір на виконання різних технологічних процесів.

Пошуки ефективних технологічних рішень та заходів в технологіях виробництва сільськогосподарської продукції ведуться через впровадження нових підходів і способів в технологічних процесах та підбір технічних засобів для якісного їх виконання. Адже багаторічними дослідженнями встановлено [1, 2], що вплив агротехнічних заходів обробітку ґрунту на врожайність с/г культур складає до $20 \%$.

Технологічні процеси по обробітку ґрунту і сівби є основними складовими частинами зональних науково обґрунтованих систем землеробства. Особливо важливе значення вони набувають в сучасних умовах, коли істотно погіршилось ресурсне забезпечення аграрних підприємств [3].

Аналіз останніх досліджень та публікацій. Дослідження питань, пов'язаних із використанням техніки в сільському господарстві, це дослідження, які пов'язані із суспільно-виробничими відносинами та становленням рівня механізації сільського виробництва.

Багаторічний досвід показує, що різні сільськогосподарські культури досить вимогливі до якості якості і виду передпосівного обробітку ґрунту. Тому у збільшенні виходу продукціі с/г культур велика роль належить розробці і впровадженню ефрективних агротехнічних прийомів і технічних засобів для обробітку ґрунту.

Аналіз даних технологій також показує, що запізнення з проведенням ранньовесняних механізованих робіт і сівби, через їх велику кількість і низьку продуктивність машинних агрегатів, приз- водить до скорочення вегетаційного періоду i, як наслідок, - до зниження урожайності основної продукції сільськогосподарських культур. На даний час при вирощуванні сільськогосподарських культур традиційно застосовують ряд технологій, що мають визначену направленість і які відрізняються одна від другої деякими прийомами, відповідно до конкретних грунтово-кліматичних умов господарств [1, 2].

Аналіз тенденцій розвитку технологій і технічних засобів для вирощування сільськогосподарських культур та дає можливість говорити про підстави для розробки і випробування системи машин для підвищення продуктивності і зниження енергетичних затрат.

Дослідження по використанню сільськогосподарської техніки стали з'являтися із появою перших зразків технічних засобів для виконання технологічних процесів у рослинництві. Відповідно до цих обставин і почали започатковуватися перші форми машиновикористання. Увага до технічного прогресу і розвитку взагалі та зокрема, до організації застосування техніки, була в ті роки досить велика.

Проблема вивчення і вдосконалення існуючих систем і комплексів машин в Україні не нова і нею займалися на протязі значного періоду часу. Дослідження даної проблеми пов'язані із становленням рівня механізації сільськогосподарського виробництва.

Наукові праці академіка Горячкіна В.П. були основою для досліджень властивостей сільськогосподарських машин та знарядь у тому числі і в порівнянні різних видів робіт через техніко-економічні показники використання машин.

Першим дослідником, який у своїх працях заклав методичні основи визначення кількості машин та організації їх використання був академік Свірщевський Броніслав Станіславович. Він визначив такі основні показники ефективності використання парку на той час: середнє річне число роботи трактора; площа, яку обслуговує один трактор; площа, яку обробляє одна машина; процент механізації; показник витрати палива [4].

Вченими Крамаровим В.С., Савченком М.3., Натанзоном І.Й. та іншими продовжено розробку основних техніко-експлуатаційних параметрів 3 урахуванням особливостей виробничих умов та технологічного комплексу робіт, які впливають на комплектування тракторних агрегатів й ефективність їх використання, а також уперше розроблено зональні нормативи потреби в машинах на 100 га орної площі й вартості однієї години роботи машин [4].

Останні періоди наукових досліджень по даній тематиці направлені на визначення раціональної структури затрат для виконання технологічних процесів через обґрунтування складу машинних 
агрегатів та режимів їх роботи. У роботах М.К. Діденка, В.Д. Гречкосія, І.І. Мельника, С.М. Бондаря [5] розроблена методика, яка дає змогу визначити раціональні структури машинних агрегатів для виконання технологічних процесів в системах технологій виробництва продукції рослинництва. Обґрунтування раціональних складів і режимів роботи машинних агрегатів повинно спиратися на систему математичних моделей та методик, які відтворюють взаємозалежність між умовами роботи і вимогами до технологічних процесів.

Виходячи із проведеного аналізу питанням досліджень роботи машинних агрегатів в технологічних процесах агропромислового виробництва займаються досить інтенсивно багато вчених. Зараз у період змін в сільському господарстві, які пов'язані з використанням нових технологій і сучасних технічних засобів, дослідження по комплектуванню та використанню машинних агрегатів у технологічних процесах рослинництва потребують нових підходів і методів реалізації їх раціональності та ефективності на виробництві. Аналітичні дослідження стосовно оцінки ефективності роботи польового культиватора «FLORIN» для передпосівного обробітку грунту під зернові культури в залежності від виробничих умов Лісостепу не проводились.

Формулювання мети роботи (постановка задачі дослідження). Питання технічного забезпечення аграрного виробництва, інноваційно-інвестиційного розвитку, вдосконалення системи матеріально-технічного забезпечення аграрного виробництва $є$ актуальними для сучасного сільськогосподарського виробництва. Сучасне сільськогосподарське виробництво характеризується якісно новим етапом технічного переозброєння. В сільськогосподарські підприємства надходить велика кількість нових тракторів, комбайнів, сільськогосподарських машин вітчизняного та імпортного виробництва. Ця техніка відрізняється високим ступенем надійності, наявністю автоматизованих систем управлення та контролю за роботою вузлів і механізмів машин, забезпечує економічний режим роботи і високу якість виконуваного процесу. Разом з тим, можливості сучасних машинних агрегатів (МА) виконувати роботу в конкретних умовах експлуатації з максимальною продуктивністю і мінімальною витратою палива часто недовикористовуються через помилки в агрегатуванні. Для усунення цих помилок слід виконувати попереднє моделювання складів агрегатів і розраховувати раціональні режими їх роботи $[6,7,8]$.

Розв'язання цих задач можливе за рахунок нових сучасних та чинних технічних засобів (робочих машин) на основі комплектування та використання при цьому критерії показників роботи та якість обробітку грунту.

Метою роботи $є$ пошук шляхів підвищення ефрективності обробітку ґрунту під с/г культури та використання технічних засобів для їх реалізації у виробничих умовах Лісостепу України через підвищення ефективності роботи та якості обробітку грунту.

Для досягнення поставленої мети необхідно вирішити наступну науково-практичну задачу, яка базується на визначенні показників роботи машинних агрегатів, які комплектуються сучасними грунтообробними машинами та знаряддями.

Викладення основного матеріалу. В технологіях виробництва сільськогосподарської продукції найбільші резерви енергозбереження, як елемента ресурсозбереження, мають способи та види механічного основного обробітку ґрунту із запровадженням і обґрунтуванням мінімально раціональних. Дані вимоги досягаються шляхом використання сучасних ґрунтообробних знарядь та вдосконалення вже відомих до цього.

Економне використання ресурсів та робочого часу $є$, зазвичай, однією із умов ефективності технології виробництва продукції сільськогосподарських культур.

У зв'язку з цим науковцями ведуться роботи по дослідженню систем та видів обробітку грунту під сільськогосподарські культури та технічних засобів для їх реалізації, в розрізі скорочення затрат робочого часу та приведених витрат. Так, як один із напрямків мінімалізації обробітку ґрунту під зернові та зернобобові культури, являється використання дискових знарядь для обробітку ґрунту, українськими виробниками сільськогосподарських машин ведуться розробки в цьому напрямку. Одним із потужних виробників машин для обробітку ґрунту на Україні $є$ Лозівський ковальсько-механічний завод (ЛКМЗ) «Лозівські машини». Даним ковальсько-механічним заводом розроблено і запущено у виробництво польового культиватора «FLORIN» для передпосівного обробітку грунту.

Комплексна оцінка експлуатаційних властивостей МА дозволяє відібрати з множини можливих варіантів лише найпридатніші для конкретних умов агрегати. При цьому важливо забезпечити взаємну відповідність параметрів окремих складових агрегату (трактор, робочі машини, додаткове обладнання), а також відповідність властивостей агрегату стосовно до вимог і природно-виробничих умов.

В такому випадку пропонується наступна методика $[6,7,8]$ виконання розрахунків з комплектування МА на основі існуючої технічної інформації, доступної широкому колу фахівців. Основними параметрами, які визначають раціональність комплектування агрегату, є його ширина захвату В та швидкість руху $V$.

Для відомої сільськогосподарської машини (машин) необхідно підібрати трактор (енергозасіб), який забезпечує максимальну продук- 
тивність агрегату при мінімальних енергозатратах на виконання заданої механізованої технологічної операції.

Можлива для реалізації тягова (корисна) потужність в агрегаті визначається за формулою:

$$
\begin{aligned}
& N_{\Pi}^{\text {Д }}=N_{\mathrm{e}}^{\mathrm{H}} \eta_{\mathrm{M}}\left(1-\frac{\delta}{100}\right)- \\
& -\frac{G\left(V_{\min } \ldots V_{\max }\right)\left(f \pm \frac{i}{100}\right)}{3,6} .
\end{aligned}
$$

де: $\eta_{\text {м}}{ }^{-}$механічний КПД трансмісії трактора; $\delta$ - буксування рушія трактора, \%; $G$ - експлуатаційна вага трактора, кН; $f$ - коефріцієнт опору коченню трактора; $i$ - схил місцевості (поля), \%; $V_{\min }, V_{\max }$ - агротехнічно допустима швидкість руху машинного агрегату, відповідно, мінімальна і максимальна, км/год.

Тягова потужність, яка обумовлюється зчіпними властивостями трактора, з врахуванням втрат потужності на буксування, самопересування і подолання підйому (спуску), розраховують за фрормулою:

$$
\begin{gathered}
N_{\text {кр }}^{\mu}=\frac{G\left(V_{\min } \ldots V_{\max }\right)\left[\lambda \mu-\left(f \pm \frac{i}{100}\right)\right]}{3,6}- \\
-N_{\mathrm{e}}^{\mathrm{H}} \eta_{\mathrm{M}} \frac{\delta}{100},
\end{gathered}
$$

де: $\lambda$ - доля ваги трактора, яка приходиться на рушій; $\mu$ - коефіцієнт зчеплення рушія трактора 3 грунтом.

Швидкість $V_{N_{\mathrm{Kp}}} a x$, при якій досягається максимальна тягова потужність трактора $N_{\text {кр }}^{\max }$, визначають по фрормулі:

$$
V_{N_{\mathrm{Kp}}} \max =3,6 \frac{N_{\mathrm{e}}^{\mathrm{H}} \eta_{\mathrm{M}}}{G \lambda \mu} .
$$

Максимально можливу тягову потужність $N_{\text {кр }}^{\max }$ розраховують по фрормулі:

$$
N_{\text {кр }}^{\max }=N_{\mathrm{e}}^{\mathrm{H}} \eta_{\mathrm{M}}\left(1-\frac{\delta}{100}-\frac{f \pm \frac{i}{100}}{\lambda \mu}\right) .
$$

Оптимальна швидкість руху агрегату $V_{\text {opt }}$ дорівнює $V_{N_{\text {кр }}}$ ax , а оптимальну ширину захвату агрегату $B_{\text {opt }}$ визначають із співвідношення:

$$
B_{\text {opt }}=\frac{N_{\text {кр }}^{\max }}{N_{\text {уд }}},
$$

де: $N_{\text {уд }}$ потужність (питома), яка приходиться на одиницю ширини захвату сільськогосподарської машини, кВт/м.

Питому потужність $N_{\text {уд }}$ визначають для комплексних багатофункційних агрегатів по формулі:

$$
N_{\text {уд }}=\frac{V_{\text {opt }}}{3,6}\left(\sum k_{\mathrm{M}(i)} \pm \sum q_{\mathrm{m}(i)} \frac{i}{100}\right),
$$

де: $\sum k_{\mathrm{m}(i)}$ - сума питомих тягових опорів сільськогосподарських машин (і-того виду), кН/м; $\sum q_{\mathrm{м}(i)}{ }^{-}$ сумарна питома вага сільськогосподарських машин (і-того виду), кН/м,

По знайденій величині $B_{\text {opt }}$ (або $B_{\text {рац }}$ ) вибирають конкретну машину (або групу машин), у якої

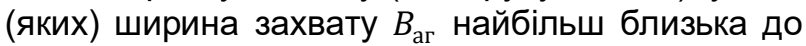
розрахункових значень, тобто:

$$
B_{\text {аг }} \leq B_{\text {opt }} \text { або } B_{\text {рац }}
$$

Після вибору машини (машин) визначають потужність $N_{\text {аг }}$, необхідну для роботи агрегату в агротехнічно допустимому діапазоні швидкостей $\left(V_{\min } \ldots V_{\max }\right)$ по форомлі:

$$
N_{\mathrm{ar}}=\frac{R_{\mathrm{ar}}\left(V_{\min } \ldots V_{\max }\right)}{3,6},
$$

де: $R_{\text {аг }}$ - тяговий опір вибраного агрегату, кН.

Тяговий опір агрегату $R_{\text {аг }}$ визначається по формулі для комплексних багатофункційних агрегатів:

$$
R_{\mathrm{ar}}=B \sum k_{\mathrm{M}(i)} \pm \sum G_{\mathrm{M}(i)} \frac{i}{100} .
$$

Раціональною швидкістю руху вибраного агрегату $V_{\text {рац }}$ буде та швидкість, при якій максимально використовуються потужностні властивості трактора, тобто $V_{\text {рац }} \rightarrow V_{N_{\text {кр }}}^{\max }$.

В умовах достатнього зчеплення рушія трак-

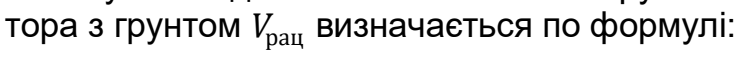

$$
V_{\text {рац }}=\frac{3,6 N_{\mathrm{e}}^{\mathrm{H}} \eta_{\mathrm{M}}\left(1-\frac{\delta}{100}\right)}{R_{\mathrm{ar}}+G\left(f \pm \frac{i}{100}\right)}
$$

При недостатньому зчепленні рушія трактора з грунтом $V_{\text {рац }}$ визначається по фрормулі:

$$
V_{\text {рац }}=\frac{R_{\text {аг }}+3,6 N_{\mathrm{e}}^{\mathrm{H}} \eta_{\mathrm{M}} \frac{\delta}{100}}{G\left[\lambda \mu-\left(f \pm \frac{i}{100}\right)\right]}
$$

Після цього розраховують тяговий КПД трактора і порівнюють його з максимально можливим для заданих умов роботи агрегату.

Тяговий (корисний) КПД трактора, який працює в агрегаті:

$$
\eta_{\mathrm{T}}=\frac{N_{\mathrm{ar}}}{N_{\mathrm{e}}^{\mathrm{H}}} \rightarrow \eta_{\mathrm{T}}^{\max }=\frac{N_{\mathrm{\kappa p}}^{\max }}{N_{\mathrm{e}}^{\mathrm{H}}},
$$

де: $N_{\text {аг }}^{\max }$ - потужність, яка необхідна для роботи агрегату в заданих умовах, кВт; $N_{\mathrm{e}}^{\mathrm{H}}$ - номінальна ефективна (експлуатаційна) потужність двигуна трактора, кВт; $\eta_{\mathrm{T}}^{\max }$ - тяговий КПД трактора, який 
максимально можливий в заданих умовах роботи; $N_{\text {кр }}^{\max }$ - тягова потуж-ність трактора, яка максимально можлива в умовах роботи агрегату, які розглядаються, кВт.

Для більш повного аналізу використання потужностних можливостей трактора розраховують значення коефіцієнтів використання тягової потужності трактора і завантаження його двигуна.

Критерію використання тягової потужності трактора і завантаження його двигуна відповідають наступні залежності:

$$
\eta_{\text {вик }}=\frac{N_{\text {аг }}}{N_{\text {кр }}^{\max }} \rightarrow 1,
$$

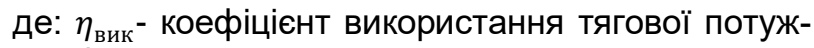
ності трактора;

$$
\eta_{3}=\frac{N_{e}}{N_{e}^{H}} \rightarrow 1,
$$

де: $\eta_{3}$ - коефіцієнт завантаження двигуна трактора; $N_{e}$ - потужність двигуна трактора, яка використовується, кВт.

При визначенні коефіцієнту завантаження двигуна зразу розраховують значення потужності двигуна трактора, яка використовується при швидкості $V_{\text {рац }}$ по формулі:

$$
N_{e}=\frac{V_{\text {рац }}}{3,6}\left\{\begin{array}{c}
R_{\text {аг }}\left[2-\eta_{\mathrm{M}}\left(1-\frac{\delta}{100}\right)\right]+ \\
+G\left(f \pm \frac{i}{100}\right)
\end{array}\right\},
$$

Продуктивність машинного агрегату за одну годину «чистої» роботи $W$ (га/год) (теоретична продуктивність) визначають по формулі:

$$
W=0,1 B V_{\text {рац }}
$$

де: $B$ - ширина захвату вибраної робочої машини, м.

Розрахункову витрату палива (питому) на одиницю виконаної роботи $q_{p}$ (кг/га) визначають за фрормулою:

$$
q_{p}=\frac{10^{-3} q_{\mathrm{e}}^{\mathrm{H}} N_{\mathrm{e}}^{\mathrm{H}}}{W}
$$

де: $q_{\mathrm{e}}^{\mathrm{H}}$ - питома витрата палива (номінальна) двигуном трактора, г/кВтгод; $N_{\mathrm{e}}^{\mathrm{H}}$ - номінальна ефективна потужність двигуна трактора, кВт.

Питомі енерговитрати машинного агрегату $Э_{\mathrm{y}}^{\text {га }(М Д ж / г а) ~ р о з р а х о в у ю т ь ~ п о ~ ф р о р м у л і: ~}$

$$
\exists_{\mathrm{y}}^{\text {га }}=42,7 q_{p} .
$$

Питомі затрати праці $\mathrm{H}_{\mathrm{y}}^{\text {га }}$ (люд*год/га) розраховують по формулі:

$$
\mathrm{H}_{\mathrm{y}}^{\text {га }}=\frac{n_{\text {мех }}+n_{\text {доп }}}{W},
$$

де: $n_{\text {мех }}$ кількість механізаторів для виконання технологічної операції, люд; $n_{\text {доп }}{ }^{-}$кількість допоміжних працівників для виконання технологічної операції, люд.

При вирішенні задач даного напрямку визначають:

- необхідну потужність для роботи агрегату з відомою сільськогосподарською машиною (машинами) в агротехнічно допустимому діапазоні швидкостей;

- розраховують необхідну ефективну потужність двигуна трактора у встановленому діапазоні швидкостей;

- визначають експлуатаційну вагу трактора, яка забезпечує достатні зчіпні властивості в умовах, які розглядаються;

- по відомих технічних характеристиках вибирають трактор, який задовольняє розрахункові значення $N_{e}$ і $G$;

- для вибраного трактора визначають швидкість $V_{N_{\mathrm{kp}}}$ ax $N_{\text {кр }}^{\max }$ трактора, які розглядаються в умовах роботи агрегату.

Результати дослідження. Розглянемо і продемонструємо наші твердження на наступному прикладі.

Для обґрунтування показників роботи культиватор польовий «FLORIN» при для виробничих умов було проведено розрахунки згідно методики, яка представлена вище, з використанням програмного пакету Microsoft Excel.

Вихідні дані: робоча машина - культиватор польовий «FLORIN»; експлуатаційна вага базової моделі $-G=10,4 \mathrm{\kappa H}$; діапазон агротехнічно допустимих швидкостей руху $-V=10 \ldots 15$ км/год; питомий тяговий опір $-\kappa_{\mathrm{M}}=2,8 . .3,2 \mathrm{\kappa H} / \mathrm{m}^{2}$; тип рушія - колісний; механічний КПД трансмісії $\eta_{\mathrm{M}}=0,92$; допустимий коефріцієнт буксування рушія $-\delta_{\text {д }}=12 \ldots 15 \%$; коефіцієнт використання зчіпної ваги $-\mu=0,6$; коефіцієнт опору коченню трактора $-f=0,18$; схил поля $-i=1 . .3 \%$; енергетичний засіб - ХТЗ-243К.20; номінальна ефективна потужність двигуна $-N_{\mathrm{e}}^{\mathrm{H}}=184,0$ кВт; експлуатаційна вага трактора $-G=82,87$ кН; питома витрата палива $-q_{\mathrm{e}}^{\mathrm{H}}=215$ г/кВт · год. Отримані результати розрахунків показників роботи культиватора польового «FLORIN» для виробничих умов Лісостепу, представлено в таблиці 1.

Аналізуючи отримані результати обґрунтування показників роботи культиватора польового «FLORIN» 3 енергетичним засобом (трактором) XТ3-243К.20 при передпосівному обробітку грунту під зернові сільськогосподарські культури для виробничих умов можна зробити висновок, що при мінімальних показниках розрахункова раціональна швидкість становить 10,2 км/год, а при максимальних - 11,25 км/год. Графічне відображення результатів обґрунтування показників роботи машинного агрегату представлено на Рис. 1 та Рис. 2. 
Таблиця 1. Показники роботи культиватора польового «FLORIN»

\begin{tabular}{|c|c|c|c|c|c|}
\hline \multirow{2}{*}{$\begin{array}{l}\text { № } \\
\mathbf{n} \boldsymbol{n}\end{array}$} & \multirow{2}{*}{ Показники } & \multirow{2}{*}{$\begin{array}{l}\text { Одиниці } \\
\text { виміру }\end{array}$} & \multicolumn{2}{|c|}{ Варіант } & \multirow{2}{*}{ Різниця } \\
\hline & & & $\min$ & $\max$ & \\
\hline 1 & Тяговий опір робочої машини, $R$ & $\mathrm{kH}$ & 24,1 & 24,3 & 0,2 \\
\hline 2 & Потужність необхідна для роботи $N_{\mathrm{ar}}$ & кBт & $66,9 \ldots 100,4$ & $67,5 \ldots 101,25$ & $0,6 \ldots 0,85$ \\
\hline 3 & $\begin{array}{l}\text { Необхідна потужність двигуна трактора, } \\
N_{\mathrm{e}}\end{array}$ & кВт & $68,98 \ldots 116,17$ & $64,38 \ldots 109,21$ & $-4,6 \ldots-6,9$ \\
\hline 4 & Експлуатаційна вага трактора, $G$ & $\mathrm{kH}$ & 82,87 & 82,87 & 0 \\
\hline 5 & \begin{tabular}{|lll} 
Максимально можлива тягова потуж- \\
ність, $N_{\text {кр }}$
\end{tabular} & кВт & 90,28 & 84,64 & $-5,64$ \\
\hline 6 & $\begin{array}{l}\text { Раціональна швидкість машинного агре- } \\
\text { гату, } V_{\text {рац }}\end{array}$ & км/год & 10,2 & 11,25 & 1,05 \\
\hline 7 & $\begin{array}{l}\text { Потужність, яка затрачається при обра- } \\
\text { ній швидкості, } N_{\mathrm{ar}}\end{array}$ & кВт & 319,8 & 301,32 & $-18,48$ \\
\hline 8 & Можлива тягова потужність трактора, $N_{\square}^{\text {д }}$ & кВт & $100,07 \ldots 78,2$ & $95,46 \ldots 71,3$ & $-4,61 \ldots 6,9$ \\
\hline 9 & $\begin{array}{l}\text { Тягова потужність що залежить від зчіп- } \\
\text { них властивостей, } N_{\kappa р}^{\mathrm{M}}\end{array}$ & кВт & $68,98 \ldots 116,17$ & $64,38 \ldots 109,21$ & $-4,6 \ldots-6,96$ \\
\hline 10 & $\begin{array}{l}\text { Коефріцієнт використання тягової потуж- } \\
\text { ності трактора, } \eta_{\text {вик }}\end{array}$ & - & 0,74 & 0,96 & 0,22 \\
\hline 11 & Тяговий КПД трактора, $\eta_{\text {т }}$ & - & 0,36 & 0,55 & 0,19 \\
\hline 12 & $\begin{array}{l}\text { Ефективна потужність двигуна трактора, } \\
N_{\mathrm{e}}\end{array}$ & кВт & 162,3 & 159,7 & $-2,6$ \\
\hline 13 & $\begin{array}{l}\text { Коефріцієнт завантаження двигуна трак- } \\
\text { тора, } \eta_{3}\end{array}$ & - & 0,88 & 0,92 & 0,04 \\
\hline 14 & \begin{tabular}{|l|} 
Розрахункова продуктивність машинного \\
агрегату за 1 год. роботи, $W$ \\
\end{tabular} & га/год & 8,16 & 9 & 0,84 \\
\hline 15 & $\begin{array}{l}\text { Розрахункова витрата палива на оди- } \\
\text { ницю роботи, } q_{\mathrm{p}}\end{array}$ & кг/га & 4,84 & 4,39 & $-0,45$ \\
\hline 16 & Питомі енерговитрати агрегату, Эу га & МДж/га & 206,66 & 187,45 & $-19,21$ \\
\hline 17 & Питомі затрати праці, $\mathrm{H}_{\mathrm{y}}^{\text {га }}$ & люд.год/га & 0,123 & 0,111 & $-0,012$ \\
\hline
\end{tabular}

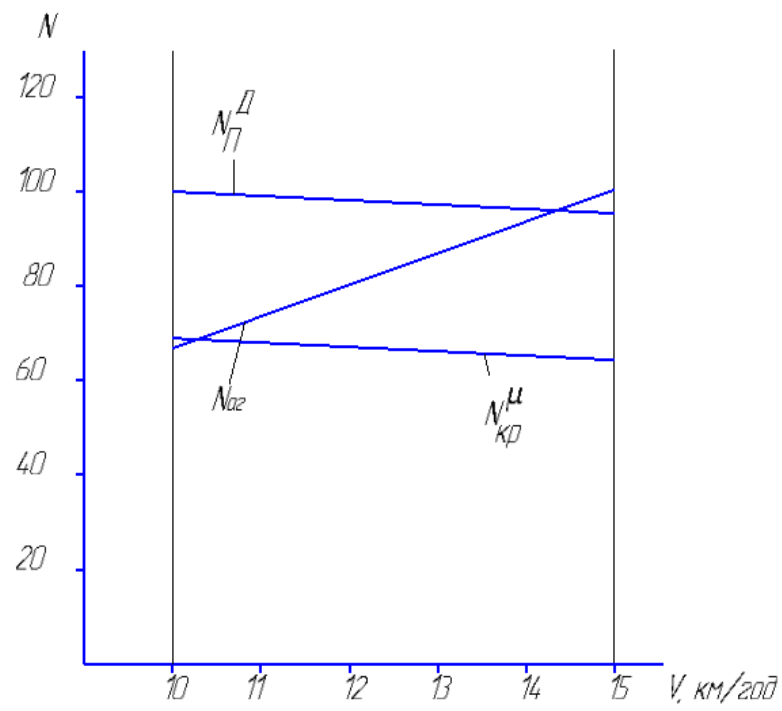

Рис. 1 Графрік відображення функції $N e=f(v)$ при мінімальних показниках роботи культиватора польового

Висновки.

1. Правильність вибору режимів роботи грунтообробних машинних агрегатів даного виду та

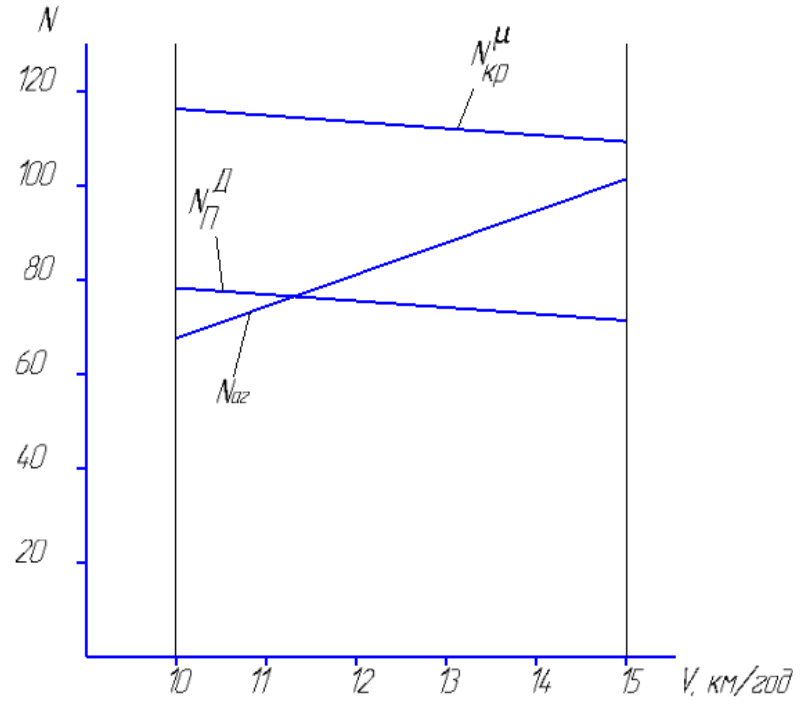

Рис. 2 Графік відображення функції $N e=f(v)$ при максимальних показниках роботи культиватора польового.

раціонального діапазону робочих швидкостей культиватора польового «FLORIN» залежить від врахування виробничих умов. Виходячи 3 
результатів досліджень роботи культиватора польового «FLORIN» з трактором Беларус 1523 при передпосівному обробітку грунту під зернові культури можна ствержувати, що найбільш ефективним режимом його роботи для виробничих умов Лісостепу $є$ робоча швидкість при мінімальних та максимальних показниках роботи відповідно складає 10,2 км/год та 11,25 км/год.

2. Отримані результати досліджень показують, що ефективність використання культиватора польового «FLORIN» при передпосівному обробітку грунту під зернові культури для виробничих умов залежить від правильного вибору показників роботи та підбору енергетичного засобу.

3. Вибір оптимального діапазону робочих швидкостей для культиватора польового «FLORIN» при передпосівному обробітку грунту під зернові культури у виробничих умовах Лісостепу дає можливість підвищити показники використання машинних агрегатів, а також скоротити витрати ресурсів на виконання технологічних процесів при виробництві сільськогосподарської продукції.

\section{Література:}

1. Танчик С. П. Плуг не відміняється. / Семен Петрович Танчик. // Пропозиція. - 2010. - №12. C. $76-77$.

2. Сайко В. Ф. Системи обробітку ґрунту в Україні / В. Ф. Сайко, А. М. Малієнко. - Київ: ТОВ ВД "ЕКMO", 2007. - 42 c.

3. Марченко В. В. Технології та технічні засоби сівби при мінімальному і нульовому обробітку / В. В. Марченко, І. Г. Котко, В.І.Опалко. // Аграрна техніка. - 2009. - №1. - С. 20.

4. Діденко М. К. Експлуатація машинно-тракторного парку: 5-е вид., доповнене і перероблене) / [М. К. Діденко та ін.]. - Київ: Вища школа, 1983. -447 c.

5. Оптимізація комплексів машин і структури машинного парку та планування технічного сервісу: навчальний посібник / [І. І. Мельник, В. Д. Гречкосій, В. В. Марченко та ін.]. - Київ: ВВЦ НАУ, 2004. - 151 c.

6. Карабаницкий А. П. Комплектование энергосберегающих машинно-тракторных агрегатов: учебное пособие / А. П. Карабаницкий, М. И. Чеботарев. - Краснодар: КубГАУ, 2012. - 97 с.

7. Маслов Г.Г. Основные принципы комплектования машинно-тракторных агрегатов: методические указания / Г.Г. Маслов, А.П. Карабаницкий, А.В. Палипин. - Краснодар: КубГАУ, 2012. - 60 с.

8. Таценко О. В. Обгрунтування показників роботи посівного комплексу ALCOR 7,5 для умов Сумщини / Олександр Володимирович Таценко // Вісник Сумського національного аграрного ун-ту: науковий журнал. - Серія «Механізація і автоматизація виробничих процесів» / Сумський НАУ. Суми, 2018. - Вип. 11. - С. 76-80.

\section{References:}

1. Tanchyk S. P. (2010), "Plug ne vidminiaietsia", Propozytsiia, vol. 12, pp. 76-77.

2. Saiko, V. F. and Maliienko, A. M. (2007), Systemy obrobitku gruntu $v$ Ukraini [Tillage systems in Ukraine], TOV VD "EKMO", Kyiv, Ukraina.

3. Marchenko V. V., Kotko I. H. and Opalko V. I. (2009), "Tekhnolohii ta tekhnichni zasoby sivby pry minimalnomu i nulovomu obrobitku", Ahrarna tekhnika. no. 1 , pp. 30.

4. Didenko M. K. (1983), Ekspluatatsiia mashynno-traktornoho parku: 5-e vyd., dopovnene i pereroblene, Vyshcha shkola, Kyiv, Ukrayna.

5. Melnyk I. I., Hrechkosii V. D. and Marchenko V. V. (2004), Optymizatsiia kompleksiv mashyn $i$ struktury mashynnoho parku ta planuvannia tekhnichnoho servisu: navchalnyi posibnyk, VVTs NAU, Kyiv, Ukrayna.

6. A.P. Karabanytskyi, M.Y. Chebotarev (2012), Komplektovanye enerhosberehaiushchykh mashynno-traktornykh ahrehatov: uchebnoe posobye, KubHAU, Krasnodar, Russia.

7. Maslov H.H., Karabanytskyi A.P. and Palypyn A.V. (2012), Osnovnye pryntsypy komplektovanyia mashynno-traktornykh ahrehatov: metodycheskye ukazanyia, KubHAU, Krasnodar, Russia.

8. Tatsenko, O.V. (2018), "Obhruntuvannia pokaznykiv roboty posivnoho kompleksu ALCOR 7,5 dlia umov Sumshchyny", Visnyk Sumskoho natsionalnoho ahrarnoho un-tu: naukovyi zhurnal, seriia Mekhanizatsiia $i$ avtomatyzatsiia vyrobnychykh protsesiv, no. 11, pp. 76-80.

\section{Аннотация}

\section{Аналитическое исследование и обоснование показателей работы полевого культиватора «FLORIN» для производственных условий}

\section{А.В. Таценко, А.В. Мартынюк, В.С. Курской}

В технологиях выращивания сельскохозяйственных культур наибольшие резервы энергосбережения и повышения продуктивности сельскохозяйственных культур имеют способы обработки почвы. Современные тенденции сельскохозяйственного производства требуют обоснования, внедрение и использование рациональных современных почвообрабатывающих орудий и совершенствование существующих технологических процессов обработки почвы.

Проанализированы последние исследования и публикации направлений повышения эффективности обработки почвы под сельскохозяйственные культуры и использования технических средств для их реализации в условиях черноземных почв Украины.

Інженерія природокористування, 2020, №2(16), с. 99 - 106 Engineering of nature management, 2020, \#2(16), p. 99 - 106 
Проведены научные исследования показателей работы полевого культиватора «FLORIN» при поверхностном обработки почвы под зерновые культуры в производственных условиях, при которых ресурсы будут использоваться наиболее эффективно. Процесс обоснования показателей работы полевого культиватора «FLORIN» проводился за счет выбора более рационального и эффективного состава и режимов работы машинных агрегатов для поверхностной обработки почвы под зерновые культуры в производственных условиях.

В статье приведены аналитические результаты исследования и обоснования показателей работы полевого культиватора «FLORIN» для производственных условий в технологиях выращивания сельскохозяйственных культур.

При исследованиях, которые проводились в соответствии с разработанной методики, определялись показатели показателей работы полевого культиватора «FLORIN».

Эффрективность использования полевого культиватора «FLORIN» при предпосевной обработки почвы под зерновые культуры для для производственных условий зависит от правильного выбора показателей работы и подбора энергетического средства для почвообрабатывающего агрегата.

Выбор оптимального диапазона рабочих скоростей для полевого культиватора «FLORIN» при возделывании почвы под зерновые культуры в производственных условиях дает возможность повысить показатели использования машинных агрегатов, а также сократить затраты ресурсов на выполнение технологических процессов при производстве сельскохозяйственной продукции.

Правильность выбора режимов работы почвообрабатывающих машинных агрегатов данного вида и рационального диапазона рабочих скоростей для полевого культиватора «FLORIN» зависит от учета производственных условий.

Ключевые слова: технологический процесс, обработка почвы, предпосевная обработка почвы, технические средства, культиватор «FLORIN», комплектование машинных агрегатов, режимы работы, показатели работы.

\title{
Abstract \\ The analytical research and substantiation indicators works field cultivator FLORIN for production conditions
}

\author{
O.V. Tatsenko, A.V. Martyniuk, V.S. Kurskoi
}

In the technologies of growing crops, the largest reserves energy saving and increasing the productivity of crops have the methods tillage soil.

Modern trends in agricultural production require justification, introduction and use of rational modern tillage tools and improvement of existing technological processes tillage soil.

The latest researches and publications directions of increase efficiency tillage soil for agricultural crops and use of technical means for their realization in the conditions chernozem soils of Ukraine are analyzed.

The process substantiation the performance of the field cultivator "FLORIN" was carried out by selecting a more rational and efficient composition and modes operation of machine aggregate surface tillage soil for grain crops in production conditions. The article presents analytical results the study and substantiation performance of the field cultivator "FLORIN" for production conditions in the technology of growing crops.

The reseach conducted in accordance with the developed methodology, the performance indicators of the field cultivator "FLORIN" were determined. The efficiency using the FLORIN field cultivator in pre-sowing tillage for grain crops production conditions depends on the correct choice of performance for the tillage unit.

The choice optimal range of working speeds for the field cultivator "FLORIN" when cultivating the soil for grain crops in production conditions makes it possible to increase use machine units, as well as reduce resource costs for technological processes in agricultural production.

The correct choice operating modes of tillage machines this type and a rational range of working speeds for the field cultivator "FLORIN" depends on the production conditions.

Keywords: technological process, tillage soil, pre-sowing tillage, technical means, cultivator "FLORIN", completing of machine aggregate, modes of operation, indicators of working.

\section{Бібліографічне посилання/ Bibliography citation: Harvard}

Tatsenko, O. V., Martyniuk, A. V. and Kurskoi, V. S. (2020) 'The analytical research and substantiation indicators works field cultivator FLORIN for production conditions', Engineering of nature management, (2(16), pp. 99 - 106.

Подано до редакції / Received: 08.08.2020 